DIGITAL COMMONS
@ UNIVERSITY OF SOUTH FLORIDA

Volume 11

Issue 1 Summer 2021

\section{ABO: Interactive Journal for Women in the Arts, 1640-1830}

Article 6

2021

\title{
Teaching Eighteenth-Century English Coercion, Seduction, And Consent In Twenty-first Century India: Eliza Haywood's Love In Excess
}

Sumi Bora

LOKD College,Dhekiajuli, sonjeevoni9@gmail.com

Follow this and additional works at: https://digitalcommons.usf.edu/abo

Part of the Dramatic Literature, Criticism and Theory Commons, Educational Methods Commons, Feminist, Gender, and Sexuality Studies Commons, and the Literature in English, British Isles Commons

\section{Recommended Citation}

Bora, Sumi (2021) "Teaching Eighteenth-Century English Coercion, Seduction, And Consent In Twenty-first Century India: Eliza Haywood's Love In Excess," ABO: Interactive Journal for Women in the Arts,

1640-1830: Vol.11: Iss.1, Article 6.

http://doi.org/10.5038/2157-7129.11.1.1238

Available at: https://digitalcommons.usf.edu/abo/vol11/iss1/6

This Pedagogy is brought to you for free and open access by Digital Commons @ University of South Florida. It has been accepted for inclusion in ABO: Interactive Journal for Women in the Arts, $1640-1830$ by an authorized administrator of Digital Commons @ University of South Florida. For more information, please contact digitalcommons@usf.edu. 


\title{
Teaching Eighteenth-Century English Coercion, Seduction, And Consent In Twenty-first Century India: Eliza Haywood's Love In Excess
}

\begin{abstract}
Classroom teaching informed by the \#MeToo movement is widespread and diverse. This paper evolves from classroom discussion with Third Semester English Major students at Lokanayak Omeo Kumar Das College, Dhekiajuli, Assam, India. The paper engages itself with \#MeToo Movement and scrutinizes the depiction of seduction in Eliza Haywood's novel Love in Excess. The paper records the students' connections between Haywood and their own desire to build consciousness among the marginalized section of women so that they voice issues of harassment in any form.
\end{abstract}

\section{Keywords}

coercion, seduction, consent, desire, power, agency, harassment, context

\section{Creative Commons License}

(c) (1) (8)

This work is licensed under a Creative Commons Attribution-Noncommercial 4.0 License 


\section{Introduction}

This paper springs from the classroom discussion with third semester English major students at Lokanayak Omeo Kumar Das College, Dhekiajuli, located at a distance of around 136 kilometers from Gauhati University, Guwahati, Assam, India, with which it is affiliated. This course module and its discussion elements aim to discuss the issue of seduction in Eliza Haywood's novel Love in Excess (1722) in the context of \#MeToo movement as put forward by the students. It further seeks to raise their consciousness regarding issues like harassment, silence, power, and violence through collaborative consideration of the text and its contexts. Along with that, it aims to make students desirous to spread these issues among the general population in the respective society which they inhabit through awareness raising program.

Students in this course have already had some foundational training in literary studies. In their first semester they are exposed to the social and literary context of the Medieval and Renaissance periods, along with a selection of poetry and plays written during these periods. In the second semester, they study the social and literary context of Restoration to the Romantic periods and selected poetry, drama, and fiction from these periods. Students get a brief orientation regarding feminist readings during a module on women's writing as a distinctive genre. Some of the authors included are Katherine Philips (1631-64), Anne Killigrew (1660-85), Mary Astell (1666-1731), and Aphra Behn (1640-89). My class on George Eliot's essay, Silly Novels by Lady Novelists (1856) in their third semester worked as a tool to facilitate discussion of issues related to feminism beyond the confines of the prescribed syllabus.

Students in the class were members of Assamese, Bodo, Nepali, Bengali, Oriya, and Marwari communities, and their responses cannot be generalized, but the experience of this project showed a range of initial perceptions of and relationships to patriarchal rules and bindings that contributed to a significant and important breadth in contemporary Indian students' responses to historical British literatures.

\section{Framing the project}

As a part of the class, I asked my students to debate and discuss a crucial issue like reading and responding to English literature from a post-colonial context. Almost all the students agreed that studying English literature in English is no longer an imposition and, given a choice, they would not opt out of it. According to them, English can open up a wider domain and make them more competent to survive in the competitive world. No doubt, studying English opens doors for better opportunities in the job market, but there are three questions that they must 
constantly grapple with, and these questions elude clear answers. As students in India, are they de-rooting themselves by electing English literature as their major subject, and knowing more about the West than their indigenous literature? What are the strategies that they can adopt to localize the Western literature in their native context? What is their position in relation to students who have opted to study regional literature like Assamese, Hindi, or Bengali?

In my literature course, George Eliot's Silly Novels by Lady Novelists (1856) is a required text for the third semester students, and female writers of the eighteenth century were engaged as a part of the extended reading connected to Eliot's criticism. In the essay, Eliot famously critiques women novelists and what Eliot sees as their lack of verisimilitude in depicting characters. This opening appraisal set up discussion and several debates amongst the students on the question of value, the nature of literary reviews, and of Eliot being influenced by the patriarchal norms of assessing a work. The students argued that Eliot's technique of combining her authoritative lexis, and her adoption of a masculine persona separated her from the women novelists she was critiquing. In the essay, Eliot regretted that women writers were squandering the opportunities they got by producing "silly novels," which were outdated and implausible, instead of writing realistic ones observing human life. Students opined that Eliot navigated the field of novel writing by women through demonstration and critique. They suggested how "silliness" can be avoided with a positive assertion that women can do and will do more as novelists like Harriet Martineau, Charlotte Brontë, and Elizabeth Gaskell had already done.

Students then applied this conversation to amatory novels of the eighteenth century: the table was set, and the students were ready to chart new territory. As 2018 was abuzz with the \#MeToo movement, reading and teaching amatory fictions in a co-educational classroom became a new type of learning experience. The class that I was teaching became the site to observe how the students understood and reacted to a movement like \#MeToo. Such a movement could be regarded as one of foreign import, but students might find that it had significant relevance in their state, Assam, India, where many women accept harassment as a natural aspect of being women, and men think it to be their duty to restrict women so that they do not deviate from their assigned roles. I kept special attention so that no situation could emerge inside the classroom conversation which demonized all men in the name of harassing women. Such an occurrence would make my class on the \#MeToo movement frivolous and could be considered simply a backlash from the females towards the males. 


\section{Phase one}

At the beginning of this project, I asked the students to form two groups to ensure their participation and involvement. The twenty-six students divided themselves into groups with nine women and four men each, which students determined was the best possible balanced representation. When I asked them the reason behind this gender-balancing they answered that both the groups should have equal number of female and male students. This, according to them, would enable multiple perspectives in both groups, which the students decided could not happen if the groups were unbalanced. This process invited further reflection, pointing to representation and balance as themselves relative concepts: in dividing students by gender, they had also created an imbalance, as the nine female students outnumbered the four male students in each group.

In the context of reviewing women writers, both groups discussed whether there was anything essential about being men and women, or male and female writing. As I found that my students used a loaded term like essentialism, I thought necessary to unpack the idea of essentialism in general and gender essentialism in particular. I told them that essentialism can be traced back to Plato who promoted the view that objects possess certain essential properties that distinguish one from another. Essentialism takes recourse in a stable and coherent, unchangeable, predictable ontology, common to all, and fixed across time and place. From certain essentialist perspectives, women's essence is seen as residing in reproductive capacities and qualities like affection, devotion, care, trustworthiness, loyalty, inner strength, patience, and resilience. Men are similarly essentialized in aggression, strength, rationality, competitiveness, independence, and experience. I selected four key feminist texts: The Second Sex (1949) by Simone de Beauvoir, The Dialectic of Sex: The Case for Feminist Revolution (1970) by Shulamith Firestone, The Reproduction of Mothering (1979) by Nancy Chodorow and Maternal Thinking: Towards a Politics of Peace (1989) by Sara Ruddick that discuss gender essentialism and asked my students to read them in detail.

I carried forward the discussion by telling my students that gender essentialism is a contested issue. Judith Butler, Julia Kristeva, and Mary Joe Frug have rejected essentialism and the idea of universal truths about gender. I also drew their attention to different strands of feminism like liberal feminism, radical feminism, third world feminism, and feminism in India. Students emerged from this section of the course able to pluralize feminines and feminisms and knowing to question assumptions of an essential. 
I also asked my students if essentialism can be avoided; can it be used only as a slur word; does it get dismissed if someone dismisses it? I gave them Anne Phillips's essay What's wrong with essentialism? Here, Phillips has convincingly noted:

From a different direction, it is sometimes said that while essentialist constructs are, in a sense, category mistakes - drawing the boundaries between people or things in the wrong place - there is not much rubbishing them as analytically wrong, because once in existence, they become part of our social reality (3).

As this module of the British literatures course is designed to bring theory and practice together, I wanted my students to be equipped enough and remain alert to a deep-seated issue like essentialism which they were very likely to encounter in the societal context.

Next, the groups considered the concomitant issues of equality and difference in reading male and female historical authors. Both groups were of the opinion that a dismissal of the principle of equality between women and men would be a disservice to the achievements like gaining social and political rights such as access to voting, education, inheritance, divorce and the like that women in different parts of the world have realized in the name of equality. At the same time, they noted that feminists cannot give up difference as it has been a significant creative and analytical tool. To substantiate their point, students quoted Joan W. Scott's argument in her essay Deconstructing Equality-versusDifference: Or, the Uses of Poststructuralist Theory for Feminism:

How then do we recognize and use notions of sexual difference and yet make arguments for equality? The only response is a double one: the unmasking of the power relationship constructed by posing equality as the antithesis of difference and the refusal of its consequent dichotomous construction of political choices.

Equality-versus-difference cannot structure choices for feminist politics; the oppositional pairing misrepresents the relationship of both terms (44).

Thus, both the groups came to the agreement that recognizing the difference between women and men is the way to get equality for women, as equality and difference were not mutually exclusive terms. This structure in which difference and equality coexisted became the key to interrogate the status of the women writers. 
Even in 2018, many students in this class initially asserted that women were biologically different from men, recognizing that those biologized assumptions had affected their life experience. For example, in Assam, certain religious institutions bar women of menstruating age from entering their precincts as they are considered to be impure. Widows are kept under strict environments, preventing them from eating non-vegetarian food, or wearing jewelry or bold colors like red under the diktats of religious scriptures. Such social constraint is carried out with a skewed view that as a result of such restrictions, the sexual urges of the widows will gradually vanish, and they will remain devoted to their dead husbands. The deprivation that women face brought to discussion the case of trans* people who are also victims of forms of exclusion and deprivation. It was a welcome affair to see that the students were generally able to move beyond the binaries of male and female bodies considered still as a norm by the society at large, engaging a nuanced sense of what sex and gender mean. Students in the class pointed out that the conventional understanding of male/female bodies was exclusionary and tended to stigmatize non-binary people as unnatural and deviant. Concomitantly, they also drew attention to the fact that trans* people too cannot be an absolute structure and there will be diversity depending on particular context, societal structure, and individual perspective. As the aim of the class was to discuss seduction, consent, and coercion of female characters in eighteenthcentury fiction, this specific conversation in class focused on gender in historical terms, but always grounded in an anti-essentialist approach.

As both groups wrestled with theorizing the notion of difference, not only in terms of their bodies but also their lived experience, they applied their approach of critiquing essentialism to reviewing women writers from the perspective of readers like Eliot. Group A was of the opinion that as women were different from men, to be given equality with men there must be different parameters for reviewing their works. One student argued that the verb given points to the differential treatment that women have received as male writers do not have to fight for equality. Group B agreed with Group A that women were different, and further added that difference should not be used for discrimination; however, Group B was against the theory of protectionism. One female student in Group B cited the example of Dr. Arupa Patangia Kalita, a highly-regarded author from Assam (a Sahitya Akademi, 2014 awardee) who famously rejected the Basanti Devi award from the Asam Sahitya Sabha, on grounds of it being in the womenonly category.

At the end of the first phase of this module, both groups had agreed that the less access that historical women writers had to experience must be questioned in a critical manner, as these limitations encompass a wide area of economics, politics, education, philosophy, geography, and history. 


\section{Phase two: reading Haywood}

As a second phase of this module, the groups were dissolved, and an open discussion method was adopted. It started with a general discussion among the students around reading during the \#MeToo movement, given the differential treatment meted to women writers, and how it waxed and waned in different time periods. They were intent upon discussing if different reviewing standards could be considered as a form of harassment. To have a first-hand experience, they asked me to suggest a novel written by an eighteenth-century women novelist they could read in the context of the movement. I suggested Love in Excess by Eliza Haywood and gave them essays on \#MeToo by Daniela Ceron (2018), BunHee Lee (2018), and Stavroula Pipyrou (2018). I also assigned essays by Kate Levin (2012), and Emily J. Dowd-Arrow and Sarah R. Creel (2016) on Haywood to give them a conceptual framework while interpreting the novel. As DowdArrow and Creel have argued:

The contemporary relevance of eighteenth-century women's texts, beyond the insights they provide us about their historical moments, is that they offer students just enough cultural and linguistic defamiliarization to take them outside themselves and to make visible compelling truths about sex, gender and feminism (1).

The students engaged with the seduction trope as found in the novel, where it was not only the men who were the seducers as conventionally assumed, but some of the women as well. One of the students explained that they would have to read the novel in its context of production to see how the seduction trope might have engaged the taste of the immediate reading public, and following that pattern enabled women writers to gain a share in the market of novel writing. Another student pointed out that with the knowledge they acquired regarding liberal feminism, radical feminism - especially, women's claim for equality, demand for voting rights, and the ideas of sex, gender, and patriarchy - they can argue that the narrow amatory subject matter of the novel is by its very restrictiveness an implicit critique and potential subversion of patriarchal expression. It is more specifically a protest against women's denial of access by that oppression through the means of literary production. A few also opined that while reading the novel we undoubtedly cannot be above our current condition (the context of reception), but we should also contextualize our reading, avoiding ahistoricism with recognition that the novel was written for a different reading public.

The students concluded that the novel can be best appreciated and assessed if we read it in the intersection of the past and the present: how the violators and their sexual misconduct would have been addressed if they happened amid the \#MeToo 
movement. Their analysis led them to ask whether the \#MeToo movement shifts the spotlight away from the crime and onto the individual character of perpetrator and victim, thus failing to tackle the structural problem of sexual violence. They further drew attention to the fact that the movement is dependent upon factors like internet accessibility, extent of education, and whether a woman lacking economic power can have a voice of her own. In a poor state like Assam where such factors are stratified, the movement cannot have an all-encompassing sway.

To validate their point regarding the status of women in Assam, the students referred to a Statement of Crime against Women for the years 2005 to 2018 issued by the Government of Assam which presented more or less an upward surge. For example, in 2005 the reported case of rape was 1238, which increased to 1909 in 2018. Hindustan Times, a leading daily reported:

While Delhi is infamous for crime against women, it is Assam, which has topped the chart for rate of crime against women in the country for the second consecutive year, as per the 2018 National Crime Records Bureau (NCRB) figures.

Rate of crime against women in Assam stood at 166 for 2018, almost three times the national average rate of 58.8 and marginally above Delhi's crime rate of 149.6 . $^{1}$

The students learned that though Assam is considered to be a state where the status of women is thought to be far better than rest of the states of India, as there are fewer instances of domestic violence, significant mobility of female and near absence of practices like dowry or sati, the present indicators and the crime statistics show that the reality is opposite to this conventional wisdom. They unanimously realized that \#MeToo provides a form of social justice that allows the sharing of taboo issues and helps break the silence surrounding serious crimes that can then be dealt with through official legal channels.

In their discussion of Love in Excess, my students were interested particularly in the expression of desire by both female and male characters. Two students pointed out that the novel gave enough space to express desire by the female characters like Alovisa and Melantha along with their male counterparts like Count D'Elmont and Baron D'Espernay. They highlighted that though such space is given, there are differential parameters conditioned by customs for each gender. Hence, when Count D'Elmont returned to Paris after a span of two years the men could easily "gain the largest share in his friendship" (2). On the other hand, the women could not do so, as the prevalent customs forbade a woman to publicly express her wishes to seek friendship with a man as it went against the rules of propriety. Alovisa's expression "without too great a breach of modesty" (10) in 
her second letter to Count D'Elmont emphasized how customs would not allow a woman to express her desire. If she did so, she censored herself, as Alovisa did to the degree which a breach of modesty was permissible. A female student observed that although a woman did not like such customs, she could curse them only secretly, as being a woman she was never to cross the boundaries 1 fixed for her. To substantiate her point, she quoted from the text where the narrator mentions "the other vented fruitless Wishes, and in secret, curs'd that Custom which forbids Women to make a Declaration of their thoughts" (2). A male student further added to the point that because of such rules Alovisa's letters to Count D'Elmont had to be sent anonymously, which led him to mistakenly identify Amena as the author, leading to her seduction. To add strength to the point one student quoted Dowd-Arrow and Creel:

...the genre of amatory fiction opens up a host of critical talking points about rape and subjectivity in our current moment ... Approaching amatory fiction from the standpoint of revealing women's desire and attacking double standards between women is only one reading of the genre's subversive potential (2).

While scrutinizing desire as expressed by the men and women in the novel, students unraveled two features. Firstly, men could openly express their desire in the public space, whereas no such space was provided to women. Secondly, women had to abide by the decrees of the society and repress their desires that did not meet the norms.

This set of observations led to a discussion regarding the issue of choice and the gendering of respect. Almost all students pointed out that the contrivances through which Count D'Elmont seduced Amena show his lack of respect for her, who, in the limited patriarchal context had virtually no choice to exercise choice. After reading Alovisa's first letter, Count D'Elmont realized the power he could wield over the opposite sex and "began to consider a Mistress as an agreeable, as well as fashionable Amusement, and resolved not to be Cruel" (5). The phrase "fashionable amusement" drove home for the students the dehumanization of women and their objectification as a source of entertainment. Count D'Elmont's resolution "not to be Cruel" does not hold ground, as after reading the second letter by Alovisa he knew well that Amena was not the sender of the first letter, but it did not deter him from seducing Amena in the Tuilleries Palace. He rationalized his actions and "to excuse himself, and lay the Blame on the Violence of his Passion" (11) without an iota of responsibility. At this point a student argued strongly that a seducer deliberately entices a person with proper knowledge without regarding the outcome of such an act. In this context, Count D'Elmont had the prior knowledge that Amena could not make informed consent 
as she became ready to meet him at the Tuilleries, carried away by his pretended love. Count D'Elmont went to the extent of using Anaret, an attendant of Amena as an apparatus by giving her a purse of louis d'ors (16). Her task was to press Amena to meet him in the rendezvous, knowing very well that as a woman, Amena would have to bear the brunt of his recklessness.

Students deliberated on whether Haywood's female characters had any options in which they could exercise choice. Amena had barely any options, some students noted. Her father, Monsieur Sanseverin, was ready to give a nod to her relationship with Count D'Elmont only as "a Suitor to his Daughter" (16) and if he vowed marriage. Count D'Elmont, on the other hand "found no inclination in himself to Marry her" (16). In both cases Amena was only a carrier of her father's honor and an object of desire for Count D'Elmont without agency of her own. Amena was torn between her duty as a daughter, as a keeper of her family's honor, and her love for Count D'Elmont. When Amena's father charged her of having a clandestine relationship with Count D'Elmont, with a frightful voice she reacted: “The Count D'Elmont never made any declarations to me worthy of your Knowledge, nor did I ever entertain him otherwise, than might become your Daughter" (13). Amena tried to balance the matter by writing a letter to Count D'Elmont as desired by her father while secretly adding another note requesting him to be in his home in the evening. It was because of her love for Count D'Elmont that she sent Anaret to tell him about the episode that compelled her to send the letter and the small note. Yet, Count D'Elmont was casual about Amena and this nature is well foregrounded when his act of seducing Amena was interrupted half-way, "he was strangely at a loss what to do with her, and made a thousand Vows if he got clear of this Adventure, never to embark in another of this Nature" (25). When they left the Tuilleries, Count D'Elmont took Amena towards his apartment. On the way when Amena said that she can stay with an acquaintance of hers, "the Count was overjoy'd to be eas'd of his fair Burthen, and setting her down at the Gate, was preparing to take his leave with an indifference" (26) without considering the ruin he had brought upon her. In their discussion, my students found that choice was a very limited privilege that women could only exercise in the male-controlled codes as found in the novel. Here, women were hardly treated with respect and the men had no qualms to run roughshod over them.

A male student pointed out that in spite of the limited choice and access to knowledge that a woman might have had in eighteenth-century England, she was held responsible if she was seduced. A classic case in his respect is Amena, who was asked to remain silent while the trope of shame was forced upon her. The conversation between Alovisa and Monsieur Sanseverin, Amena's father, was taken as a point of reference by another student who, in their essay, quoted: 
Now, said she, if you should suffer your rage to break out in any publick Manner against the Count, it will only serve to make your Daughter's Dishonor the Table-talk of all Paris... which should he do, the shame wou'd be wholly her's, for few wou'd condemn him for accepting the offer' $d$ Caresses of a Lady so young and beautiful as Amena (30-31).

Because he was a man Count D'Elmont's crime was absolved, shifting the entire responsibility to the woman, Amena. Though Amena's self-esteem was hurt by the careless attitude of Count D'Elmont, she could not come out into the public and expose his violation. She only requested of Alovisa:

I have two favors, Madam, yet to ask of you (rejoin'd she) neither of them will, I believe, seem difficult to you to grant, that you will make use of the Power you have with my Father, to let my departure as sudden as possible, and that while I am here, I may never see Count D’Elmont (44-45).

A student made an opposite point that Amena's act of departure to the monastery without pleading her innocence could be considered as an act of subverting the patriarchal norms of honor. By acting in such a way, Amena tried to claim that her honor was her own, however mute it may have appeared to be. In this discussion students unearthed the strategies of silence imposed on women during the eighteenth century that gave seduction a wide scale circulation, as nobody knew the status of the other. They found that the situation was further aggravated as women were influenced by the patriarchal mindset to not be in any position to question the status quo but took it to be natural and circulated it.

Another student proposed that they should look into how a woman who seduced a man was considered. The student argued that it would give the issue of seduction a sustained and balanced overview to show the other side of the picture. The case in this regard was the changing of beds by Melantha, who occupied Melliora's bed on the night of a ball. The ball was arranged by her brother, Baron D'Espernay, who employed a considerable range of strategies so that Count D'Elmont could seduce Melliora. Because of Melantha's deception, Count D'Elmont actually slept with her instead of Melliora, his object of desire. Another student carried forward the discussion by pointing that when the deception came to light, it pointed out the different parameters applied to judge a woman if she carried out the same act of seduction as a man. Though in this particular case both Count D'Elmont and Melantha were equally complicit, it was she who was labeled as the deviant for not conforming to her sex. To corroborate the point, the 
student drew attention to the reaction of Baron D'Espernay when he discovered his sister's trick:

Few Men, how amorous soever themselves, care that the Female part of their Family be so, and he was most sensibly mortify'd with it, . . . that wicked woman has betray'd the Trust I repos'd in her, and deceiv'd both you and me; rise, continued he, throwing open the Curtains, thou shame of thy Sex, everlasting Blot and Scandal of the Noble House thou art descended from; rise, I say, or I will stab thee here in this Scene of Guilt (120-121).

The lie that Melantha told shows her lack of power to assert. Her brother did the same trick, but it was accepted without any question. It dawned upon the students that a woman was basically considered household property, keeper of family honor with no say of her own. She was required to conform to the patriarchal structure of the good woman or else she brought shame to her entire sex. Students brought to the forefront that identical rules were not applied to judge men and women who did an identical act. For example, seducing someone, which should be denounced by men and women, was accepted when a man was the perpetrator, but if a woman did the same thing, she was to be expelled.

\section{Integrating the world of the text and the lived world}

After this sustained discussion of the issues at historical distance, my students scrutinized the world they inhabit and recognized that there are several maladies that affect women in Assam. There are instances where a girl child is not allowed to go to school; there is no job security for women in the unorganized sector; wife battering is a common occurrence; low wages, a form of economic harassment, are given to women; women have a set dress code; and again, for any act of sexual harassment a woman is held responsible. Under the current circumstances, the \#MeToo movement could be an effective means to address these societal ills. Thus, students translated the \#MeToo movement to their own lived reality making it transnational and relevant in their day- to- day lives.

The students argued that Love in Excess provides an example of how to scrutinize how patterns of violence operated insidiously and were never questioned by the victims. They gradually realized that reading and discussing an eighteenth-century novel with their contemporary knowledge of feminism made it an engaging and enabling read. It no longer remained merely a text under the got to read section which they had to read to clear examination; rather it metamorphosed into a text in the want to read category, a text they read with pleasure and felt connected to. This ultimately established a dialogue between the past (text) and the present (reader): by engaging with Haywood's novel through contemporary developments 
a new text was generated. To contextualize the movement and carry its momentum from the online world to the streets, and to mobilize toward real-world change, the students pledged that in their respective locations where they will: (i) give effort to build consciousness among the marginalized section of women so that they voice their issues; (ii) generate awareness among the men to make them realize the need to be respectful and ethical towards the opposite sex; (iii) make a synergetic examination of the sources where power inequalities are produced, cultivated, and sustained and entertained hope of breaking a circle of violence against women.

\section{Conclusion}

I aimed my project to make a heady mixture of theory and praxis while teaching Eliza Haywood's novel Love in Excess inside the classroom through the framework of \#MeToo movement. I created an environment that inspired my students to ask themselves how it would be if they could connect Love in Excess with the world that existed beyond the classroom; do texts taught inside the classroom have potentiality to bring real life changes? Towards that end, I brought the issue of seduction, harassment and consent, for examination and discussion and adopted the method of minimal intervention by keeping the discussion openended. I acted as the moderator facilitating the students to engage with those vital issues collectively and feel confident enough to face situations which may challenge their pre-conceived notions of seduction, haraslsment, and consent, as they go into the field to raise awareness. I believe that the methods I adopted in this classroom discussion of Eliza Haywood's Love in Excess can act as a sample of how a text can facilitate understanding of actual situations in daily life and intervene wherever required.

\section{Works Cited}

Dowd-Arrow, Emily J. and Creel, Sarah R. “"“I Know You Want It”: Teaching the Blurred Lines of Eighteenth-Century Rape Culture." ABO: Interactive Journal for Women in the Arts, 1640-1830: Vol. 6: Iss. 2, Article 2.

Haywood, Eliza. Love in Excess or The Fatal Enquiry (fourth edition), Black Swan, 1722..

Parashar, Utpal. "Not Delhi, Assam has the highest crime against women in India." Hindustan Times, Guwahati, 11 January 2020, www.hindustantimes.com. Accessed 17 January 2020 
Phillips, Anne. "What's wrong with essentialism?" Distinktion: Scandinavian Journal of Social Theory. 11 (1). 2010: pp. 47-60.

Scott, Joan W. "Deconstructing Equality-versus-Difference: Or, the Uses of Poststructuralist Theory for Feminism." Feminist Studies, vol. 14, no. 1 Spring, 1988: pp. 32-50.

"Statement of Crime against Women for the Year 2005 to 2018." Government of Assam, Home and Political, Assam Police. police.assam.gov.in Accessed 10 January 2020

https://www.google.com/url?sa=t\&source=web\&rct=j\&url=https://police. assam.gov.in/sites/default/files/swf_utility_folder/departments/assampolic e_webcomindia_org_oid_8/menu/information_and_services/statement_of crime_against_women_for_the_year_2005_to_2018_0.pdf\&ved=2ahUK Ewjn3oja14fqAhVN73MBHeomDP8QFjABegQIARAI\&usg=AOvVaw3 THBCY95895DtNwIV98zOe

${ }^{1} 149.6$ shows the rate of crime per 1,00,000 people; however, many women fail to report such crimes. 